\title{
Csatahajók lokátorral megvívott éjszakai tengeri ütközete Guadalcanalnál 1942-ben mbresz
}

$\mathrm{M}$ ialatt az elővéd két csoportjának cirkálói és rombolói az amerikai hajókat támadták, Kondo a Savosziget nyugati oldalán tett egy kört, hogy megvárja, amíg az elővéd hajói felderítik a terepet, és át tudja tekinteni a helyzetet. A beérkező jelentések alapján úgy tűnt, az ütközet a legjobb úton halad, és az amerikai erők máris vereséget szenvedtek. Az AYANAMI jelentette, hogy elsülylyesztett egy cirkálót és egy rombolót, egy másik rombolót pedig súlyosan megrongált. A többiek szintén süllyedő és égő amerikai cirkálókról és rombolókról számoltak be. Kondo biztos volt benne, a főerők bevetésére nem is lesz szükség, ezért hajóit visszafordította északnyugat felé, hogy biztos távolságban várják ki, amíg a cirkálók és rombolók végképp megtörik az amerikaiak ellenállását, és tisztára söprik az utat Henderson Field felé.

Nemsokára azonban kezdtek befutni az első figyelmeztető jelzések az ATAGO parancsnoki hídjára. A TAKAÓRÓL jelezték, megfigyelőik egy amerikai csatahajót láttak, dél felé. Közben a NAGARÁ-n is felismerték a valódi helyzetet, és Kimura tengernagy rádión jelentette Kondónak: „Az Esperance-fok előtt két ellenséges csatahajó tart nyugat felé, Guadalcanal északi partjai mentén!"

Kondo azonban figyelmen kívül hagyta ezeket a jelzéseket, hiszen addig minden jelentés arról számolt be, a térségben csak amerikai nehézcirkálók tartózkodnak. Tíz perccel éjfél előtt megfordította hajóit, vissza Guadalcanal felé, és jelezte, készüljenek fel a repülőtér ágyúzására. A három hajó még be sem fejezte a fordulatot, amikor megfigyelőik szinte egyszerre vették észre a SOUTH DAKOTÁ-t, tőlük délnyugatra, mintegy tíz kilométeres távolságban.

Ezúttal rögtön nyilvánvaló volt, hogy nem nehézcirkálóval állnak szemben. Anélkül, hogy Kondo utasításaira várt volna, a KIRISHIMA parancsnoka, Iwabuchi Sanji sorhajókapitány, azonnal kiadta a tüzparancsot. Egészen addig azonban Henderson Field bombázására készültek, ezért a csatahajó lövegtornyaiban a repülőtér lövetésére alkalmas repeszgránátokat készítették elő a tüzeléshez. Percekig tartott, mire a lőszerraktárakból az ágyúkhoz szállították a páncéltörő lövedékeket, s ez idő alatt a KIRISHIMA a repeszgránátokkal lőtte amerikai ellenfelét.

Az ATAGO parancsnoki hídján egy rövid ideig abban reménykedtek, talán a HIEl került elő, amelynek sorsáról Kondónak nem volt biztos információja. A cirkálóról megvilágították az ismeretlen hajót, és miután azt amerikai csatahajóként azonosították, a két nehézcirkáló ágyúi is tüzet nyitottak. Az ATAGO nyolc torpedót is kilőtt az amerikai hajó felé, azok azonban, célt tévesztettek.

Már az első sortűzből több találat érte a SOUTH DAKOTÁ-t, amelyen egymást követték a becsapódások. Rögtön az első találatok egyike megrongálta az előárbóc

32. ábra. A KIRISHIMA csatahajó. A hajó fő fegyverzetét $8 \mathrm{db} 356 \mathrm{~mm}$-es ágyú képezte

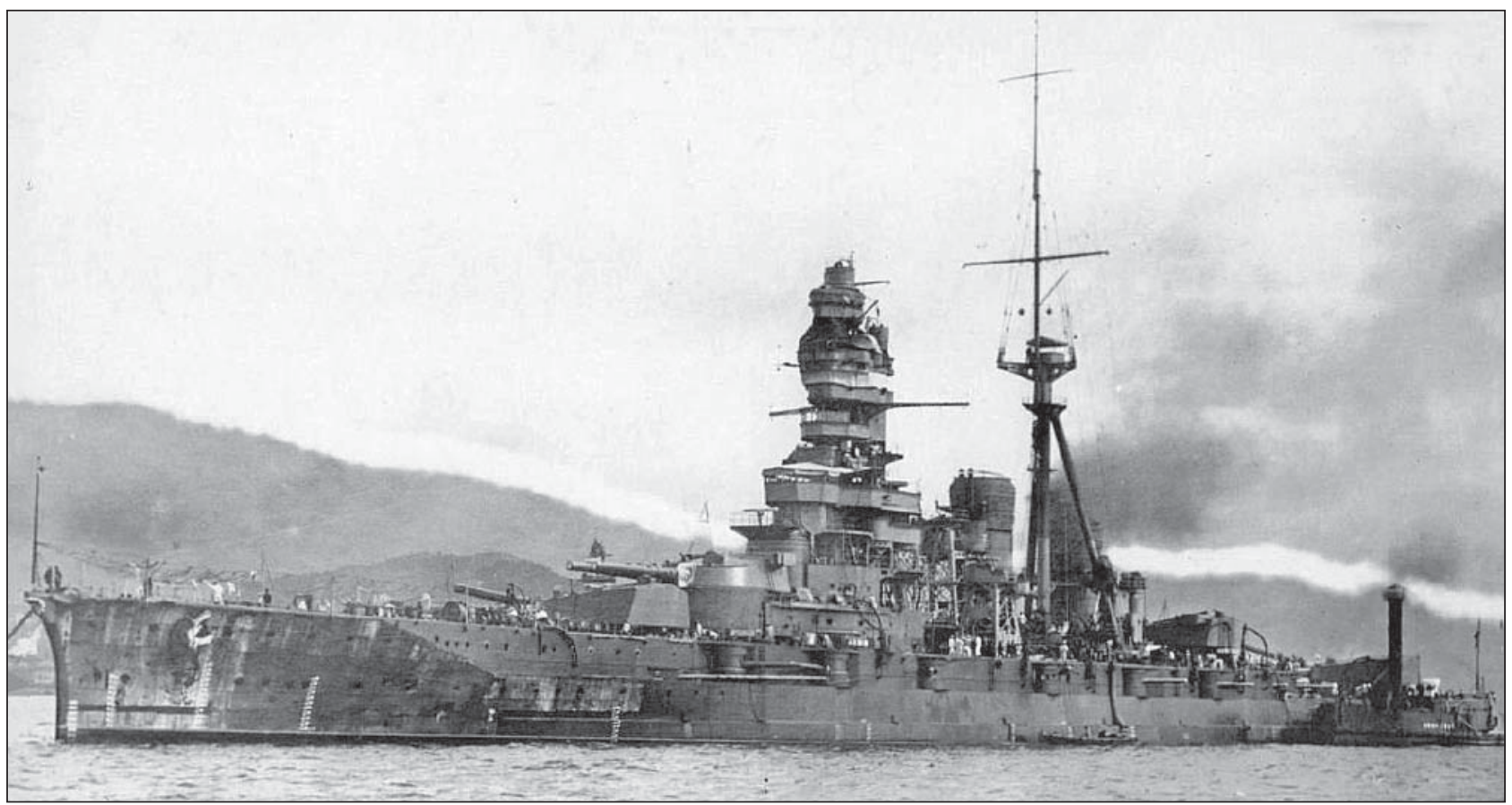




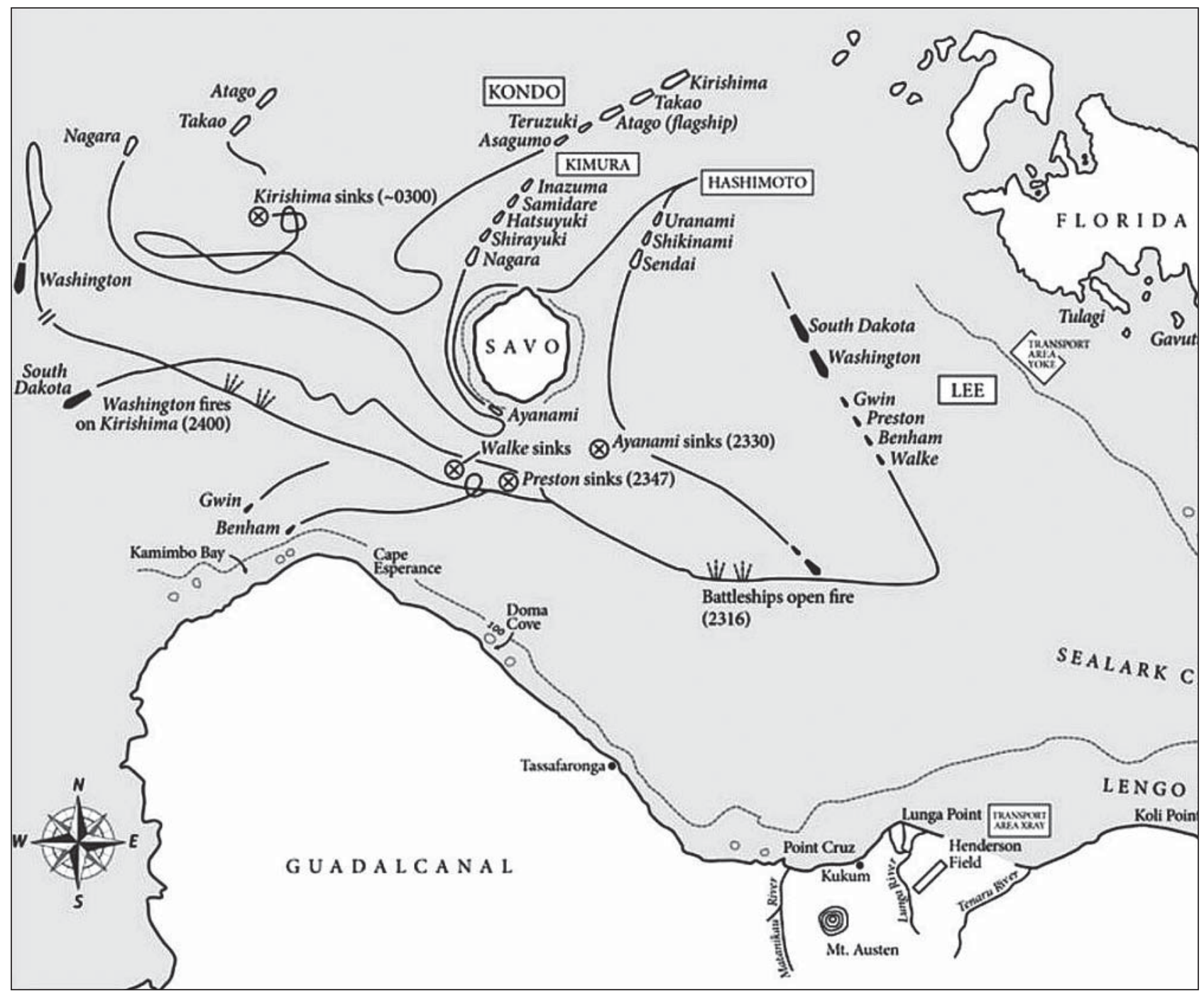

33. ábra. Az ütközet vázlatrajza

tetején elhelyezett fő tűzvezető állást, amely beszorult, és nem lehetett oldalra fordítani. A radarkezelő szobát több találat is érte, a berendezések tönkrementek, illetve súlyosan megrongálódtak, a radarkezelők elestek, vagy megsebesültek. A rádió- és radarantennák megrongálódtak, a fel-

34. ábra. A SOUTH DAKOTA testvérhajója, a MASSACHUSETTS csatahajó központi irányító helyisége a radar indikátor képernyővel és a túzvezető rendszer elemeivel

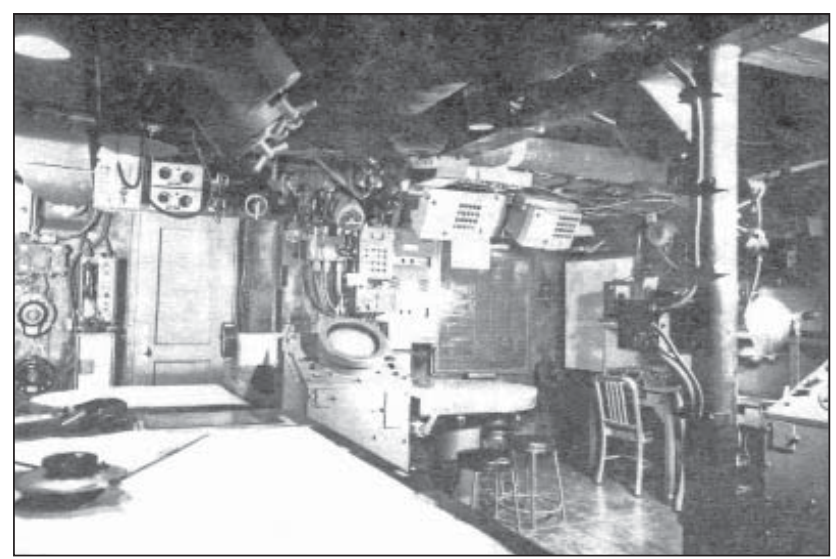

építményekben több helyen tüzek törtek ki. Egy 356 mm-es páncéltörő gránát a hármas lövegtorony barbettáját találta el, és arról lepattanva a hajó belsejében robbant, nagy tüzet okozva a lövegtorony mellett. A torony lőszerraktárát elővigyázatosságból elárasztották.

35. ábra. A Tulagi partjainál elsüllyedt KIKUZUKI romboló roncsai napjainkban

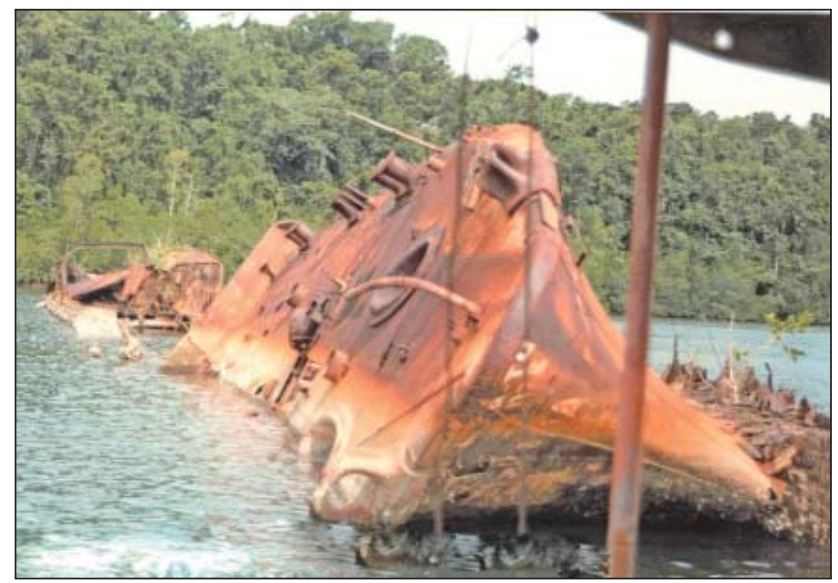




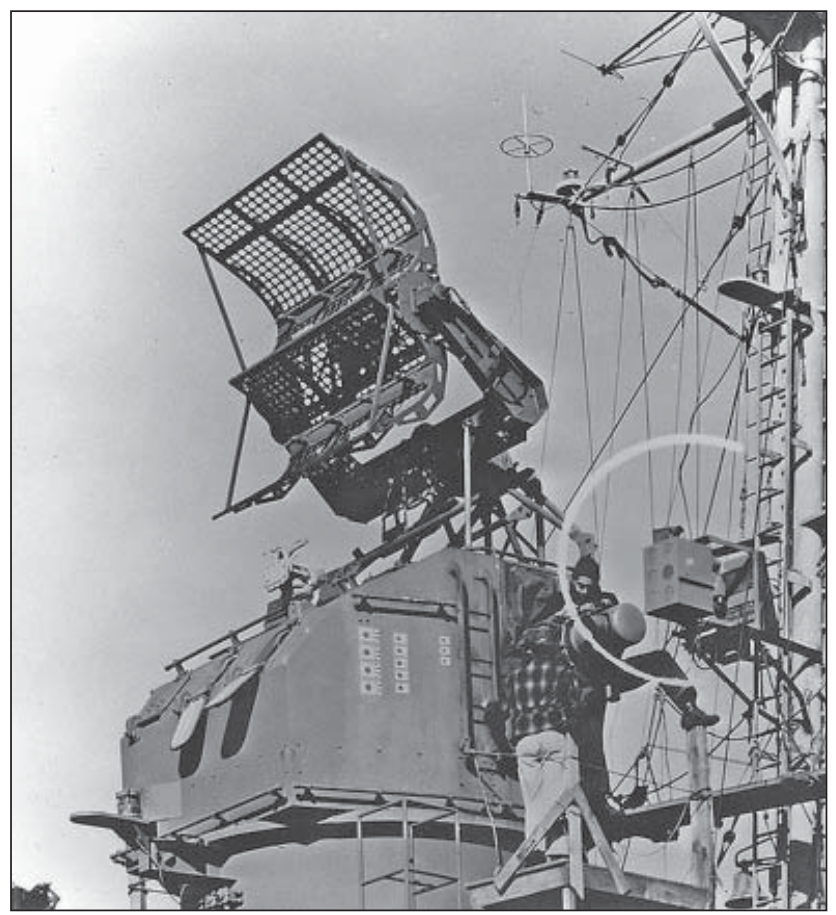

36. ábra. Mark IV tűzvezető radar egy amerikai rombolón

Pontban éjfélkor az ATAGO parancsnoki hídján az egyik őrszem felkiáltott: „Egy másik hajó is van az első előtt, egy nagy csatahajó!” Rögtön ezután egy másik megfigyelő már jelentette is: „A KIRISHIMÁ-t teljesen eltakarják a becsapódások!"

A WASHINGTON 406 mm-es lövegei, a SENDAI-ra leadott három sortűz után nem szólaltak meg újra, s a csatahajó csak 127 mm-es lövegeiből adott le néhány sortüzet a japán cirkálókra. Mialatt a SOUTH DAKOTA tüzérsége ész nélkül lövöldözött mindenfelé, és ezzel teljesen magára vonta a japánok figyelmét, a tőle balra, és valamivel előtte haladó WASHINGTON csendben meglapulva tartotta a $290^{\circ}$-os irányt, miközben Lee a radar által jelzett három nagy célpontra összpontosította figyelmét. A radar jelezte, hogy az egyik célpont nagyobb a másik kettőnél, és ebből az amerikaiak már sejtették, hogy egy csatahajóval állnak szemben. A Savo-sziget takarása miatt azonban a radar egy időre szem elől tévesztette a célpontokat, amelyek csak akkor kerültek ismét elő, amikor Kondo északnyugat felé fordult a hajóival. A WASHINGTON tatja mögött haladó SOUTH DAKOTA a radar holtterében volt, így mikor a nagy

\section{7. ábra. A PRESTON romboló (DD 379-es), a csata előtt}

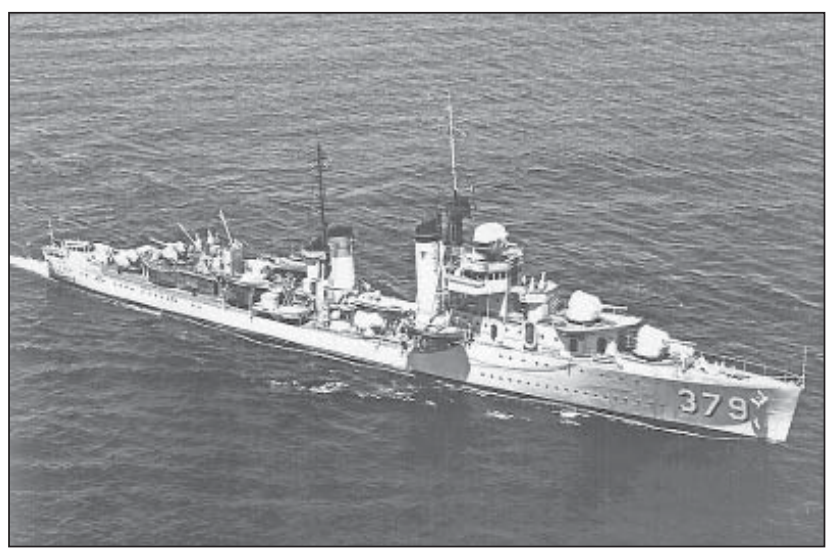

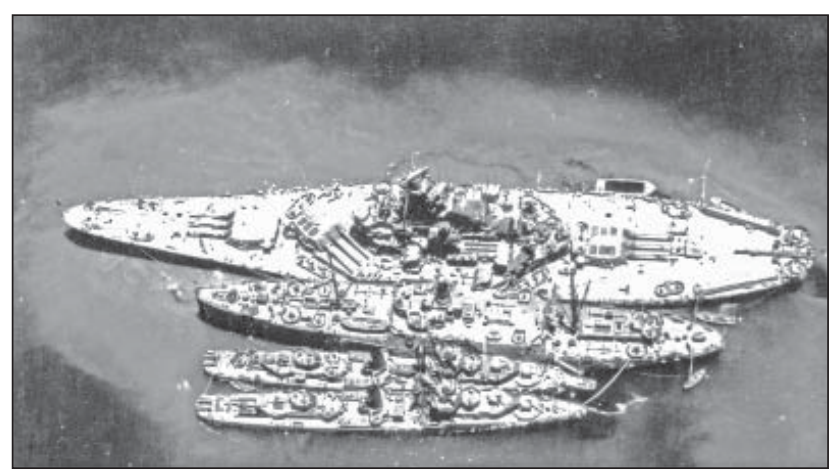

38. ábra. A sérült SOUTH DAKOTA csatahajó és két romboló a PROMETHEUS mühelyhajó mellett, a csata után, javítások közben

célpont ismét feltűnt a képernyőn, az amerikaiak nem voltak benne egészen biztosak, hogy nem a SOUTH DAKOTÁ-t látják-e.

Lee így nem mert tüzet nyitni a hajóra, amíg azt minden kétséget kizáróan nem azonosították. Mikor azonban a japán hajók tüzet nyitottak a SOUTH DAKOTÁ-ra, a torkolattüzek és az ATAGO fényszórói jól megvilágították őket, és az amerikai csatahajóról vizuálisan is azonosíthatóak voltak. Éjfélkor a WASHINGTON ágyúi 7600 m-es távolságról tüzet nyitottak a japán csatahajóra. A 406 mm-es lövegek a KIRISHIMÁ-t lőtték, a 127 mm-esek megosztva, két-két lövegtoronnyal tüzeltek a KIRISHIMÁ-ra és az ATAGÓ-ra, miközben az ötödik $127 \mathrm{~mm}$-es torony folyamatosan lőtte a világítólövedékeket a célpontok fölé. Az ágyúk radar alapján tüzeltek, a becsapódások vízoszlopait azonban az optikai távolságmérőkkel figyelték ${ }^{11}$, és azok alapján módosítottak az irányzékon. Az amerikai ágyúk a tőlük telhető legnagyobb tűzgyorsasággal tüzeltek, és nem egészen három perc alatt öt sortüzet adtak le. Az első sortüz rövidre sikerült, a másodiknál azonban már találatot jelentettek.

Az ötödik leadott sortűz után azonban a radar néhány pillanatra szem elől tévesztette a célpontot, amit a radarkezelők ismét úgy értékeltek, hogy sikerült elsüllyeszteni az ellenséges hajót. Az ágyúk beszüntették a tüzelést, a megfigyelők azonban rövidesen jelentették, az ellenséges csatahajó még a felszínen van, és három lövegtornyából még mindig tüzel. A WASHINGTON ágyúi ekkor ismét tüzet nyitottak, és a harmadik sortűzzel újra sikerült eltalálniuk a KIRISHIMÁ-t.

Újabb négypercnyi tüzelés után Lee ismét beszüntette a tüzelést. A KIRISHIMA ekkor már lángokban állt, ágyúi elhallgattak. A hajó észak felé próbált menekülni, majd az amerikai hajókról is jól láthatóan balra fordult, és körözni kezdett, ami nyilvánvalóvá tette, hogy kormányszerkezete is megsérült.

A WASHINGTON ágyúi még mintegy tíz percen át követték a KIRISHIMÁ-t, azonban már nem nyitottak újra tüzet. A 406 mm-es lövegek alig hét perc alatt 75 lövést adtak le az ellenségre, míg a csatahajó 127 mm-es ágyúi összesen 227 lövést. Az első értékelés alapján a 406 mm-es ágyúk nyolc biztos találatot értek el a KIRISHIMÁ-n, amit később kilencre módosítottak. Még később, a japán túlélők visszaemlékezései és a hajó roncsainak vizsgálata alapján, arra a következtetésre jutottak, a KIRISHIMÁ-t ezeken kívül még legalább három 406 mm-es gránát találhatta el, mélyen a vízvonal alatt, amit a WASHINGTON megfigyelői nem vettek észre.

Az ütközet során a WASHINGTON egyetlen találatot kapott, a japán cirkálók $15 \mathrm{~cm}$-es ágyúitól. A gránát az előár- 


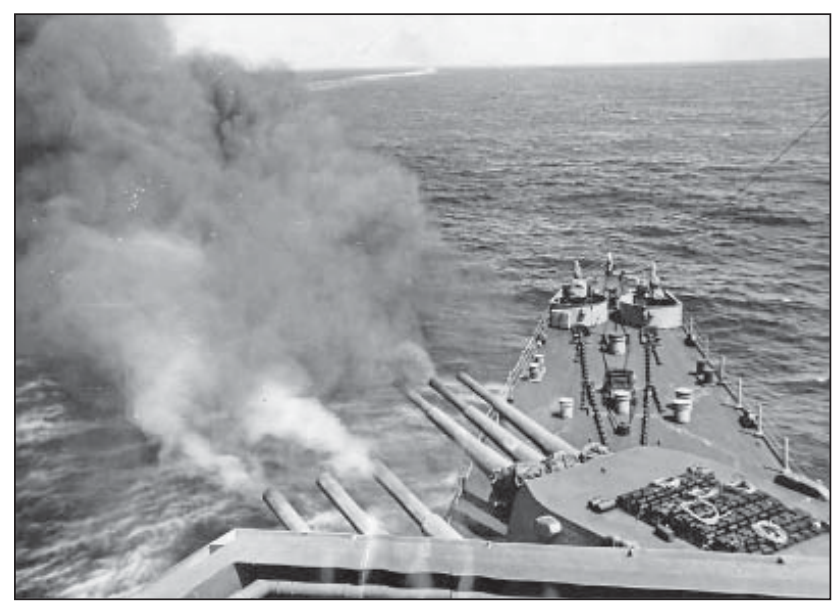

39. ábra. A SAN FRANCISCO nehézcirkáló ágyúi tüzelnek egy lőgyakorlaton

bócot találta el, de nagy kárt nem okozott, csupán a légtérfigyelő CXAM radart tette üzemképtelenné.

A radar alapján tüzelő $406 \mathrm{~mm}$-es lövegek tehát legalább 12-16\%-os találati arányt értek el éjszakai harcban, csaknem nyolc kilométeres távolságról. A két hajó majdnem ellentétes irányban haladt, a WASHINGTON 26 csomós, a KIRISHIMA 28 csomós sebességgel, az ágyúknak tehát úgy kellett követniük a célpontot, hogy a hajók 54 csomós relatív sebességgel haladtak el egymás mellett, viszonylag nem túl nagy távolságban. A WASHINGTON lövegtornyainak hét perc alatt több mint $100^{\circ}$-ot kellett fordulniuk, hogy az ágyúkat a célon tudják tartani. Ilyen körülmények között, ilyen magas találati arányt elérni komoly bravúrnak számított, amit csak a radarkészülékek használata tett lehetővé.

A SOUTH DAKOTA csak a $127 \mathrm{~mm}$-es lövegeivel vett részt az összecsapásban, 406 mm-es ágyúi csak az ütközet legvégén adtak le egyetlen sortüzet, amelyet meglehetősen találomra a NAGARA felé lőttek ki, de találatot nem értek el. A csatahajót összesen 27 gránát találta el, amelyek nagyrészt a felépítményeken csapódtak be. Egy kivételével mindegyik gránát a japán cirkálók és rombolók 120-203 mm-es ágyúitól származott, s a lövedékek legalább harmada nem robbant fel. A SOUTH DAKOTA legénységéből 38 tengerész elesett, 60 megsebesült.

A becsapódások a csatahajón minden rádió- és radarantennát tönkretettek vagy megrongáltak, a hatból négy tűzvezető radar teljesen tönkrement. A tűzvezető rendszer üzemképtelenné vált és nem müködtek a rádiók sem. A hajó nem tudta felvenni a kapcsolatot a WASHINGTONnal, és miután a radarok sem működtek, a sötétben azt sem tudták, merre jár a zászlóshajó, és tulajdonképpen

40. ábra. A SAN FRANCISCO nehézcirkáló, mellette vontatóhajók

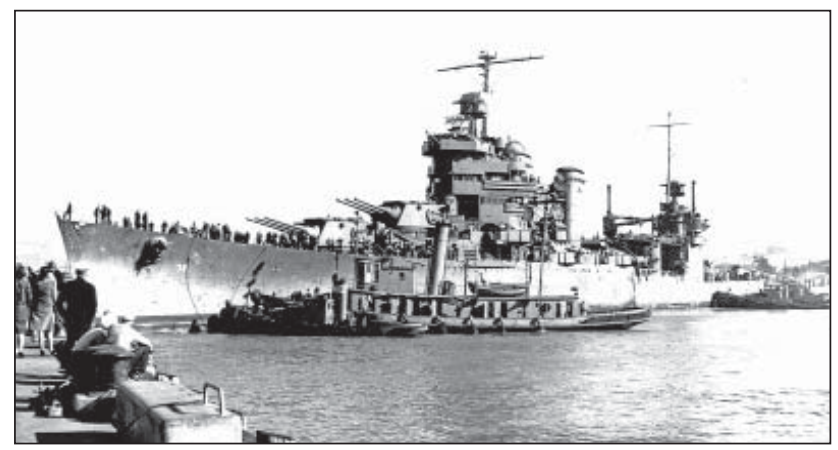

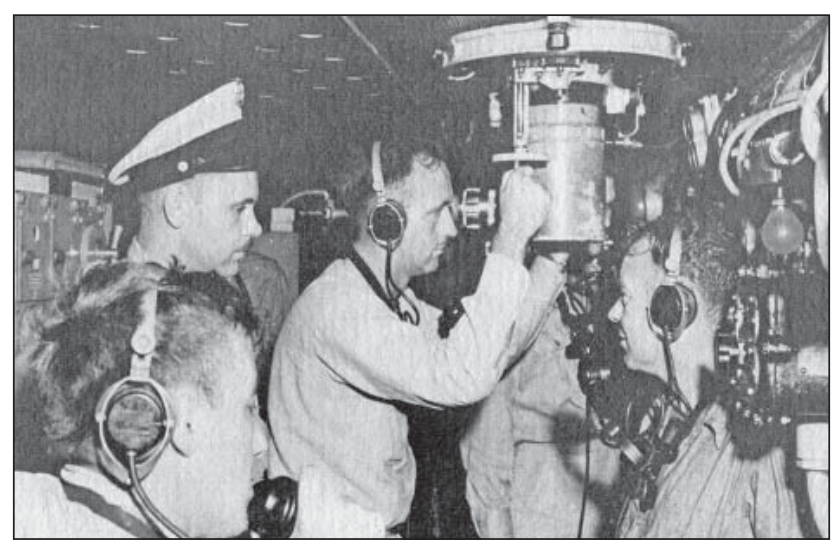

41. ábra. A tüzérek a SOUTH DAKOTA egyik $406 \mathrm{~mm}$-es lövegtornyának periszkópján figyelik a lövedékek becsapódását

hogyan is áll az ütközet. Thomas Gatch kapitány ezért délnyugat felé fordult, és a maximális 27 csomós sebességre gyorsítva igyekezett kivonni hajóját a veszélyes zónából, miközben valamennyi nélkülözhető embere a tüzeket oltotta, és a sebesülteket igyekezett biztonságba helyezni.

A két japán nehézcirkáló nem sokat tudott tenni. Kondo fél kettőig követte az amerikai csatahajókat, és időnként leadott rájuk néhány sortüzet. A TAKAO és az ATAGO az ütközet során összesen 39 torpedót lőtt ki, amelyek azonban mind célt tévesztettek. Az ATAGO két találatot kapott a WASHINGTON 127 mm-es ágyúitól, ezek azonban nem okoztak komolyabb sérüléseket. 01:30 után a japánok szem elől tévesztették az amerikai hajókat. Kondo lemondott Henderson Field bombázásáról, és elrendelte a viszszavonulást.

A WASHINGTON radarjain észlelték a japán hajókat, de nem tudták azonosítani őket. Mivel még mindig nem tudták, hol van a SOUTH DAKOTA, Lee nem adott tǔzparancsot, nehogy tévedésből saját hajóra nyissanak tüzet. A WASHINGTON megkerülte Guadalcanal északi csücskét, majd 01:30-kor délnyugat felé fordult, és 18 csomós sebességgel haladva, elhagyta a csatateret. A mögötte haladó SOUTH DAKOTA nagyjából ugyanezt az irányt követte.

A megdőlt és égő KIRISHIMA eközben tehetetlenül keringett körbe. Már a WASHINGTON első sortüze olyan közel vágódott be, hogy a felcsapódó vízoszlopok a hajóra hullottak vissza, és elárasztották a parancsnoki hidat. A második sortűz már telibe talált és tönkretette az első lövegtornyot. A hajót ezt követően egymás után érték a becsapódások. Több gránát a vízvonal alatt találta el a hajót, ahol olyan pusztítást végeztek, hogy a japánok biztosak voltak benne, torpedótalálatokat kaptak. A tüzek miatt a hátsó lőszerraktárt rövidesen el kellett árasztani, a csatahajónak tehát csak a B lövegtornya maradt üzemképes. Az egyik gránát a hajó kormányát találta el, a kormánylapát beszorult, és a hajó bal felé fordulva körözni kezdett. Miután a jobb oldalon becsapódó gránátok által okozott nagy vízbetörések miatt a hajó erősen jobbra dőlt, a kapitány parancsára elárasztották a bal oldali gépházat, hogy a dőlést kiegyensúlyozzák.

A 406 mm-es amerikai gránátok félelmetesen hatékonynak bizonyultak, és olyan óriási pusztítást végeztek, hogy a KIRISHIMA túlélői biztosak voltak benne, hajójukat legalább 20 nehézgránát, és 5 vagy 6 torpedó találta el. A csatahajót a WASHINGTON tüzérsége olyan gyorsan kiütötte, hogy védekezni is alig maradt ideje. Az összecsapás alatt a hajó nehézágyúi összesen 117 gránátot lőttek 


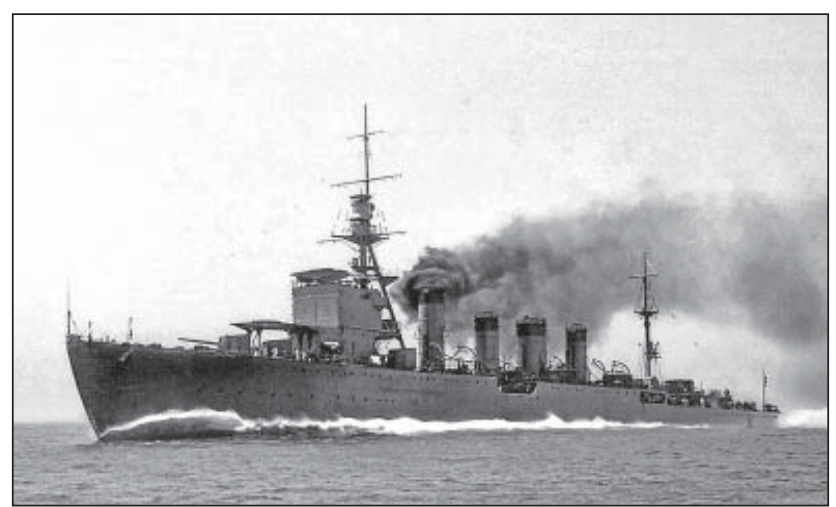

42. ábra. A japán SENDAI cirkáló próbajáraton, 1924-ben

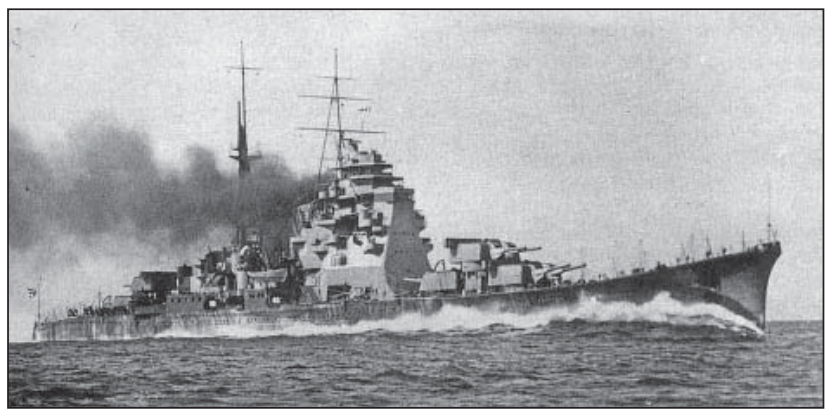

43. ábra. A japán TAKAO nehézcirkáló

ki, de nagy többségüket az ütközet első fázisában, a SOUTH DAKOTÁ-ra. Ebből a 117 gránátból viszont csak 27 volt páncéltörő gránát, az összes többi az eredetileg a repülőtér bombázására szánt repeszgránát, amelyek az erős páncélzatú csatahajók ellen hatástalanok voltak. A japánokat váratlanul érte az amerikai csatahajók felbukkanása, és már nem volt idejük a repülőtér ágyúzására előkészített repeszgránátok cseréjére. ${ }^{12}$

A KIRISHIMA parancsnoki hídján egy ideig úgy tủnt, van még remény a hajó megmentésére, vagy legalább arra, hogy a közeli szigeteknél partra futtassák. A tüzeket sikerült megfékezni, az egyik hajtómű még működött, a hajó tehát nem vesztette el teljesen mozgásképességét. $A$ kárelhárítók azonban nem tudtak bejutni az elárasztott kormánykamrába, a csatahajó tehát továbbra is irányíthatatlan volt. Iwabuchi kapitány jelzett a NAGARÁ-nak, vegye vontatókötélre a csatahajót, a cirkáló kapitánya azonban, tengeralattjáró veszélyre hivatkozva, megtagadta a segítségnyújtást. A kétségbeesett Iwabuchi ekkor rádión egyenesen az Egyesített Flotta főparancsnokságához fordult, arra kérve őket, utasítsák a NAGARÁ-t a vontatásra. Az üzenet azonban soha nem ért célba. A NAGARA helyett így végül

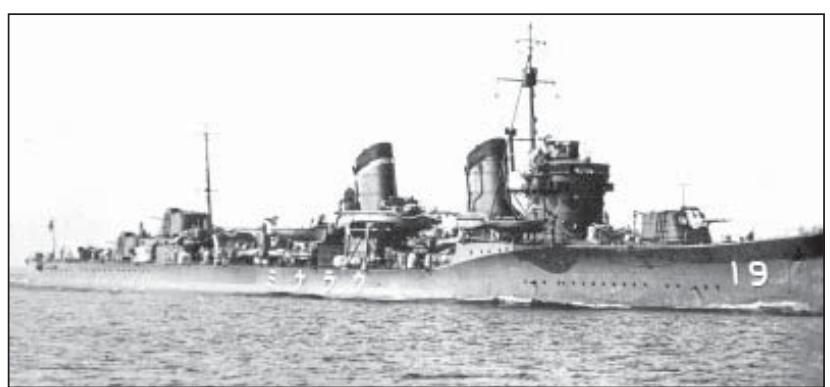

45. ábra. A japán URANAMI romboló

a csatahajó közelében tartózkodó rombolók vették vontába a KIRISHIMÁ-t, a kis hajók azonban jóformán megmozdítani sem bírták a már mélyen a vízbe merült, hatalmas hajótestet.

A csatahajón főleg a vízvonalat ért találatok okoztak gondot, mivel az itt betörő víz a páncélfedélzetet árasztotta el, tehát nem a hajó mélyén, hanem a felső fedélzeteken, a vízvonal körül keletkezett jelentős többletsúly, ami miatt a súlypont nagyon magasra került. Valahányszor ellenárasztással próbálkoztak, a hajó mindig átdőlt az éppen elárasztott rekesz felöli oldalra. A KIRISHIMA úgy dülöngélt jobbra-balra, mint egy keljfeljancsi, és időnként annyira megdőlt, hogy lehetetlen volt a fedélzeteken kapaszkodás nélkül megállni.

Iwabuchi kapitány végül feladta a harcot, és elrendelte a hajó elhagyását. A túlélők a fedélzeten gyülekeztek, ahol a kapitány rövid beszédben köszönte meg helytállásukat, majd miután levonták a zászlót, elénekelték a nemzeti himnuszt, az uralkodót éltették. Ezt követően először a császár arcképét helyezték biztonságba, majd a sebesülteket szállították át a csatahajó mellé álló két rombolóra. A kiürítés még zajlott, amikor nem sokkal 03 óra után az addig erősen jobbra dőlő KIRISHIMA hirtelen ismét átbillent a bal oldalra, és gyorsan dőlni kezdett. A bal oldalán álló romboló csak gyorsan hátrafelé tolatva tudta elkerülni, hogy a csatahajó ráboruljon.

A KIRISHIMA 03:23-kor felborult és elsüllyedt. Az idejében elrendelt kiürítésnek köszönhetően a csatahajó személyzetének nagy részét a rombolóknak sikerült kimenteniük. A KIRISHIMA legénységéből összesen 209 ember vesztette életét.

A csatahajón kívül a japánok elvesztették az AYANAMI-t is, amelyet hajnali két órakor az URANAMI romboló sülylyesztett el, miután felvette a legénységét. $A z$ amerikaiak szintén elvesztettek még egy hajót, a BENHAM rombolót, amelyet másnap este szintén ki kellett üríteni. A rombolót végül a GWIN ágyúi küldték hullámsírba, miután a BENHAMra kilőtt négy torpedójuk egyike sem robbant fel. A csatában az amerikaiak mindösszesen 242, a japánok 249 tengerészt vesztettek.

\section{4. ábra. A WASHINGTON csatahajó, és egy teherhajó az új-kaledóniai Nouméa kikötőjében, 1943 tavaszán}

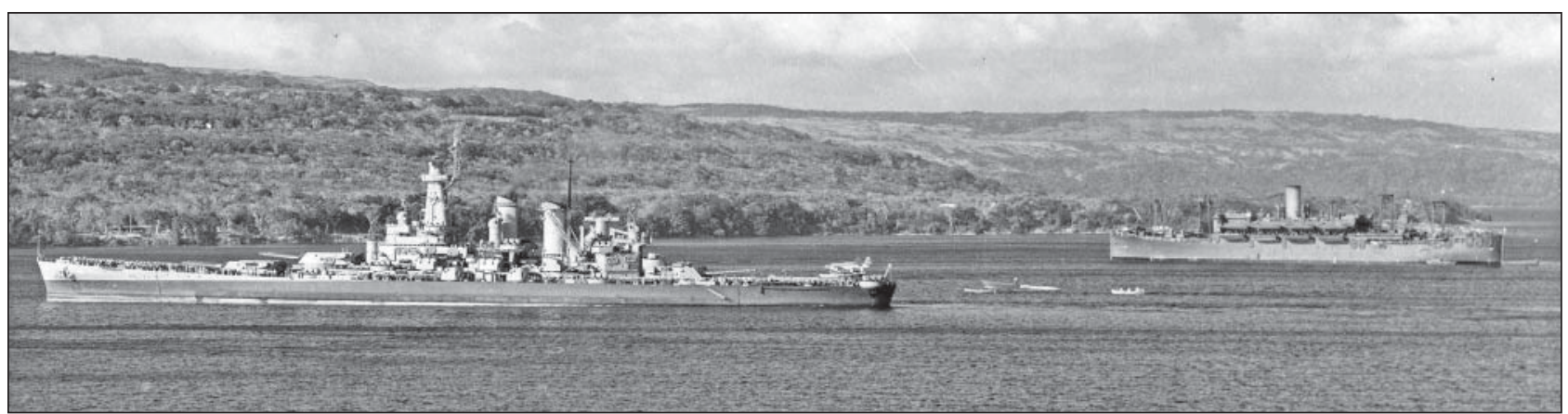




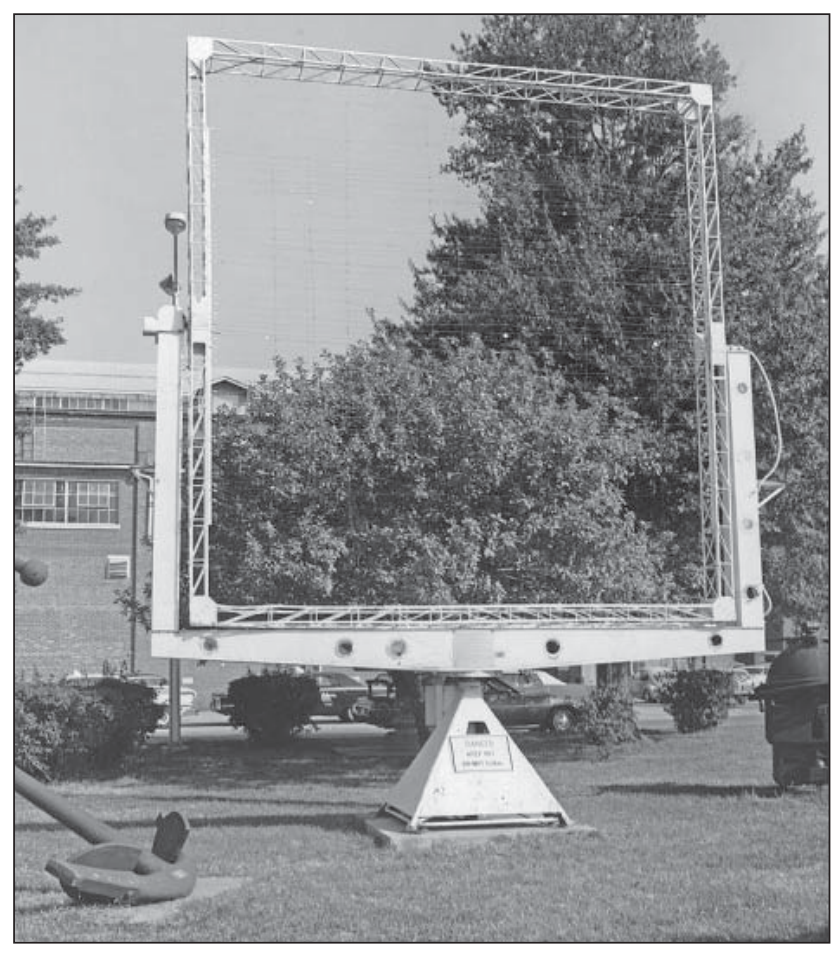

46. ábra. Egy XAF radar antennája

Yamamoto reakciója az újabb vereségre nem volt olyan heves, mint két nappal korábban. Kondo, aki Abe-val ellentétben jó kapcsolatokkal rendelkező és befolyásos embernek számított, nem kapott semmilyen elmarasztalást, vagy büntetést, és továbbra is megtarthatta posztját.

A japán hadvezetés még mindig nem akarta feladni Guadalcanalt és tovább akarták folytatni a harcot. November végén azonban a szövetségesek offenzívát indítottak Új-Guineán, és az eredetileg Guadalcanalra szánt japán csapatokat végül itt kellett bevetni. A szigetekre továbbra is csak a rombolók éjszakai járataival tudtak utánpótlást eljuttatni, ami messze nem volt elég a csapatok szükségleteinek kielégítéséhez.

Decemberben a japán vezérkar végül kénytelen volt szembenézni a vereséggel, és miután a császár is jóváhagyta a javaslatot, december 31-én elrendelték a Guadalcanalon állomásozó csapatok evakuálását. A kiürítést 1943. február 9-ig sikeresen, nagyobb veszteségek nélkül végrehajtották.

A vereségek hatására végre a japán hadihajókon is szélesebb körben alkalmazásra kerültek a radarkészülékek. A japán kutatók 1943-ra kifejlesztették az első, mikrohullámon működő haditengerészeti radarjaikat, amelyek már elég pontosak voltak ahhoz, hogy akár a tűzvezetés irányítására is alkalmasak legyenek. ${ }^{13} \mathrm{~A}$ haditengerészet tisztjeinek idejétmúlt hozzáállása azonban továbbra is megmaradt. A japánok kizárólag csak támadásban tudtak gondolkozni, és a radart továbbra is a védekezés eszközének tekintették, aminek használata szinte szégyen volt a szamuráj tradíciókon nevelkedett tisztek számára. A radarokat soha nem kötötték össze a tűzvezető számítógépekkel, és a gyakorlatban csak légtérfigyelésre használták.

$\mathrm{Az}$ amerikaiakat ezzel szemben szinte megbűvölte a saját technológiájuk és a hadihajók fedélzetén hamarosan kialakult az az állapot, amit radarfüggőségnek neveztek el. A tengerészek szinte minden problémás helyzetben a radartól remélték a választ a kérdésekre, és egyre kevésbé hagyatkoztak a hagyományos módszerekre. Már a SOUTH
DAKOTA parancsnoka is felfigyelt erre a jelenségre, amit így írt le: „A radarokhoz való ragaszkodás, és a beléjük vetett bizalom mértéke bámulatba ejtő. Miután a hajó elvesztette mind az SG, mind az SC készülékeket, ennek a tisztekre és a legénységre gyakorolt pszichológiai hatása a lehető legcsüggesztőbb volt. Ezeknek az eszközöknek az elvesztése mindenkiben azt az érzést keltette, mintha bekötötték volna a szemüket."

A Guadalcanal körül közel fél éven át elhúzódó harcok anyagcsatáiban végül a japánok erőforrásai merültek ki, míg az Egyesült Államok hadereje a hátország hatalmas ipari potenciáljára támaszkodva nemcsak pótolni tudta veszteségeit, hanem még növelni is képes volt erejét. Guadalcanal volt a japánok utolsó kísérlete arra, hogy ismét magukhoz ragadják a kezdeményezést; a háború további részében már kénytelenek voltak passzív védekezésre szorítkozni.

A Guadalcanal körüli harcok végképp megtörték a Császári Haditengerészet Midway-nél már megroppant gerincét is. A sziget körül folyó harcok kimenetelében egyértelmủen a radar használata jelentette a fordulópontot, és ez billentette át az amerikai oldalra a mérleg nyelvét. A KIRISHIMA pusztulása világossá tette, már a japán haditengerészet jobb taktikája, tengerészeinek fegyelmezettsége és magas harci morálja sem tudja ellensúlyozni az amerikai technológia fölényét.

A Savo-szigetnél vívott ütközetek jelentőségét Eric Hammel így összegezte: „1942 november 12-én a Császári Haditengerészet rendelkezett jobb hajókkal, és jobb taktikával. 1942. november 15-e után azonban elvesztették a győzelembe vetett hitüket, és azt a hadászati mélységet, amellyel szembe tudtak volna nézni az erősödő US Navyvel, és annak rendkívüli mértékben fejlődő fegyvereivel és taktikájával. 1942. november 15-e után a japánok már nem lettek jobbak, míg ellenben az US Navy már nem szünt meg egyre jobbnak lenni."

\section{FORRÁSOK}

Norman Friedman: Naval radar. Naval Institute Press, 1981; Norman Friedman: U.S. Battleships: An illustrated design history. Naval Institute Press, 1985;

William Garzke - Robert Dulin: Battleships: United States Battleships, 1935-1992. Naval Institute Press, 1995;

Mark Stille: USN Cruiser versus IJN Cruiser, Osprey, 2009;

Lawrence Burr: US Fast battleships, 1936-1947. Osprey, 2010;

Masataka Chihaya - Yasuo Abe: IJN Kongo, Battleship

1912-1944. Profile Publications, 1971;

http://www.navweaps.com/.

\section{JegYzeteK}

11 A későbbi radarok már erre is képesek voltak, sőt, a saját lövedékek pályáját is követni lehetett velük, és mérni a sebességüket.

12 A KIRISHIMA ágyúi egyetlen bizonyított találatot értek el a SOUTH DAKOTÁ-n, egy páncéltörő gránát a hátsó lövegtorony barbettáját találta el. Újabb kutatások azt feltételezik, talán a KIRISHIMA néhány repeszgránátja is eltalálhatta az amerikai csatahajót.

13 A japánoknak már 1942 őszére sikerült az, ami a németeknek a háború végéig sem. Egy olyan radar kifejlesztése, ami elég könnyű és kis méretű volt ahhoz, hogy akár repülőgépek fedélzetén is használni tudják. A magnetronnal kapcsolatban elért eredményeiket a japánok egyébként sosem osztották meg a németekkel. 